\title{
Ethno-Religious Identification and Support for Interreligious Violence: A Study of Muslim and Christian Students in Indonesia and the Philippines
}

\author{
Agnieszka Kanas \\ Erasmus University Rotterdam
}

\section{Peer Scheepers and Carl Sterkens}

\section{Radboud University Nijmegen}

\begin{abstract}
This study examines mechanisms and conditions under which ethnoreligious identification is related to support for out-group violence. It uses unique survey data collected among religious minorities and majorities in conflict and non-conflict regions in Indonesia and the Philippines. We find that strong ethno-religious identification is positively related to support for out-group violence. This relationship is fully mediated by the perception of out-group threat, suggesting that ethno-religious identification facilitates the perception of out-group threat, which, in turn, is positively related to support of violence. While the experience of communal violence increases support for interreligious violence, it does not influence the relationship between perceived group threat and support for violence. Interestingly, there is some evidence that the negative influence of intergroup contact on violence support is weaker for those who experienced communal violence.
\end{abstract}

\section{INTRODUCTION}

Ethno-religious-based conflicts are disturbingly prevalent in all parts of the world. A recent study of the PEW Research Center shows that

Address correspondence and reprint requests to: Agnieszka Kanas, Department of Public Administration and Sociology, Erasmus University Rotterdam, Postbus 17383000 DR Rotterdam, the Netherlands. E-mail: kanas@essb.eur.nl 
communal violence had increased over the period between 2010 and 2017, with 56 out of 200 countries reporting high or very high social hostilities involving ethnicity and religion in 2017 (PEW 2019). In Ambon, the Moluccas in Indonesia, one of the regions examined in this study, the communal violence between Christians and Muslims in 1999-2000 caused an estimated 5,000 deaths and roughly 700,000 displacements (International Crisis Group 2002). Communal tensions escalated again into violence in September 2011 when a Muslim motorcycle driver unexpectedly died in a Christian area in Ambon (International Crisis Group 2012a), exposing the vulnerability of the region's reconciliation process.

Likewise, the Philippines has been locked in a continuous conflict on its southern island of Mindanao involving terrorist violence and military attacks that have led to thousands of killed and displaced millions (Zartman and Hopmann 2011: 199). The establishment of the Bangsamoro Autonomous Region in Muslim Mindanao (BARMM) in March 2019 can be seen as the culmination of a decades-long peace process between the Philippine government and the Moro Islamic Liberation Front (MILF). However, violence, kidnapping for ransom, and communal tensions continued after the destruction and depopulation of Marawi city - one of our research locations-after a 5-month battle in 2017. In mid-January 2020, the Philippine military rescued Indonesian fishers who were taken hostage by suspected Islamic State (ISIS)-affiliated Abu Sayyaf Group (ASG) militants a few months earlier in Sulu province. After liberation, suspected ASG militants abducted immediately five other Indonesians fishing in Philippine waters. Philippine military and Moro National Liberation Front factions continued to clash with the Philippine military in Sulu, Tawi Tawi Basilan, and North Cotabato provinces (International Crisis Group 2019, 2020b).

Although ethno-religious differences are not the sole reason for conflicts in the Moluccas (Indonesia) and Mindanao (Philippines), ethnic and religious identification together with social, economic, and political inequalities between the indigenous population and internal migrants from other parts of the country are considered important triggers of conflict in both countries (Zartman and Hopmann 2011; Schulze 2017).

Given the prevalence of ethno-religious-based prejudice and violence in many regions of the world, finding mechanisms and conditions explaining out-group prejudice and the violent forms it can take is of critical importance. This research is guided by two lines of inquiry: efforts to identify important mechanisms explaining the relationship between ethno-religious 
identification and support for interreligious violence, as well as conditions under which these explanatory processes take place. Although a great deal of empirical research has examined the relationship between ethnic and religious identification and out-group prejudice (see Jackson and Hunsberger 1999; Scheepers and Eisinga 2015 for overviews of empirical findings), considerably less attention has been devoted to mechanisms and conditions under which these identities are related to violent behavior. Based on Social Identity Theory (SIT) (Tajfel and Turner 1979; Tajfel 1982), we expect ethno-religious identification to be positively related to support for out-group violence. We set out to include mechanisms derived from ethnic group conflict theory (Scheepers, Gijsberts, and Coenders 2002) and contact theory (Pettigrew and Tropp 2006), explaining the role of ethno-religious identification in support for out-group violence. In addition, we examine these sets of relationships while conditioning on the actual exposure to intergroup conflict, which is known to affect support for violence (e.g., Rouhana and Bar-Tal 1998; Bauman and Leech 2012).

Previous research on the link between religious identification and outgroup prejudice has predominantly focused on ethnic and religious majorities in Western countries, namely White Christians in the United States (see Scheepers and Eisinga 2015 for an overview). Only a few studies have focused on prejudicial attitudes among religious minorities, but again these studies were mainly concerned with Western countries (Verkuyten 2007; Verkuyten and Yildiz 2007; 2010; Ysseldyk et al. 2012). Thus, there is a gap in our knowledge, whether group identification processes are equally important for majorities and minorities in social contexts where intergroup relations are influenced by severe communal conflict. This study contributes to previous research by examining the relationship between ethno-religious identification and support for interreligious violence among both religious majorities and minorities, moreover, in contexts where relations between the two largest religious communities-Christians and Muslims - are far from harmonious.

\section{RESEARCH CONTEXT}

In this study, we focus on four ethnically and religiously diverse regions, i.e., Maluku and Yogyakarta (Central Java) in Indonesia, and in and around what is since 2019 called the BARMM and Metro-Manila in the Philippines. These four regions of Indonesia and the Philippines provide 
a unique opportunity to answer our research questions. In all regions, there are sizable ethnic and religious communities, which are alternating in the majority and minority position (at both local and national level), power and status relations, and some regions have histories of communal conflicts. More specifically, while the majority of the population in Indonesia and Yogyakarta is Javanese Muslim, Ambon island has long been a mainly Ambonese Christian region, albeit with a substantial Ambonese Muslim population and other Muslim migrant groups. ${ }^{1}$ Moreover, Muslims, who in Indonesia have the most political power because of their sheer number, have, on average lower socio-economic status than Christians, who are a minority group with little political influence. Still, Christians are being perceived as gaining too much strength in political and economic domains (Mujiburrahman 2006; Van Bruinessen 2018; Setiawan et al. 2021), in line with the observation that in poor economic circumstances, the dominant group usually blames the subordinate group for economic hardship (Quillian 1995).

In the Philippines, the vast majority of ethnic groups are Christian (mainly Roman Catholic). In contrast, in BARMM, the majority of the population belong to the Bangsamoro and are Muslims. Moreover, Christians in the Philippines enjoy both political power and have higher socio-economic status than Muslims, regardless of the region. Finally, whereas Yogyakarta and Metro-Manila have had relatively peaceful histories of relations between ethno-religious groups, Maluku and BARMM have had severe ethno-religious conflicts. ${ }^{2}$

\section{ETHNO-RELIGIOUS IDENTIFICATION AND SUPPORT FOR OUT-GROUP VIOLENCE}

SIT offers a particularly useful approach to understand the relationship between ethno-religious group membership and intergroup relations (Tajfel and Turner 1979; Tajfel 1982). According to SIT, group membership provides knowledge and emotional value, which are central to achieve a sense of self-concept (Tajfel and Turner 1979; Roccas et al. 2008; Ysseldyk, Matheson, and Anisman 2010). Moreover, social identification with a group motivates individuals to distinguish their group from others to achieve and maintain positive self-esteem (Tajfel and Turner 1979; Tajfel 1982; Ysseldyk, Matheson, and Anisman 2010; Spears 2011). Concerning religious groups, the need for achieving and preserving self-esteem is likely to increase beliefs that one's religion teaches the 
absolute truth or is a unique source of morality, which reinforces "us" versus "them" distinctions and is likely to foster perceived superiority, i.e., in-group glorification relative to other religious groups (Rowatt et al. 2002; Roccas, Klar, and Liviatan 2006).

While the positive relationship between in-group identification and in-group favoritism does not necessarily induce out-group derogation, this may happen when groups find themselves in a conflicting situation or when the in-group's identity is threatened by the out-group (Hinkle and Brown 1990; Brewer 1999). In both Indonesia and the Philippines, social cleavages occur along ethnic and religious lines, and in some regions, there is ongoing communal conflict and violence. Based on the previous, we expect that because of these tensions, ethno-religious identification will be positively related to support of interreligious violence (Hypothesis 1).

\section{PERCEIVED AND ACTUAL GROUP THREAT AND THE QUALITY OF INTERGROUP CONTACT}

According to ethnic group conflict theory, actual or perceived competition over scarce resources such as affordable housing or secure employment and conflict over cultural values between groups create circumstances in which identification with an in-group may feed perceptions of out-group threat (Scheepers, Gijsberts, and Coenders 2002).

In both countries, there are regions with strong resentments between ethnic Christians and Muslims who differ in socio-economic status and political influence and have been involved in hostilities and sectarian conflict, at least in some regions. Therefore, we expect ethno-religious identification to be positively related to perceptions of out-group threat, which, in turn, is positively related to support for violence. Previous research has shown that intergroup threat plays a central mediating role in fostering prejudice and support for intergroup conflict (e.g., Tausch et al. 2007; Schmid et al. 2008; Stephan, Ybarra, and Morrison 2009; Maoz and McCauley 2009). However, relatively little attention has been paid to the mediating role of intergroup threat across regions with different intergroup conflict levels. Based on previous studies, we consider this mediating role of out-group threat and argue that the perception of threat should be thought of as a key determinant of support for out-group violence.

Moreover, we propose that this relationship may be stronger, particularly for those who have directly experienced communal violence, such as losing a home or beloved ones (e.g., Rouhana and Bar-Tal 1998; 
Bauman and Leech 2012). Based on the preceding, we hypothesize that perceived out-group threat explains (some of) the positive relationship between ethno-religious identification and support for violence on behalf of the ethno-religious in-group (Hypothesis 2). In addition, we expect that the positive relationship between perceived out-group threat and support for out-group violence is stronger for those who experienced actual violence than those who did not (Hypotheses 3 ).

Contact theory provides an additional mechanism explaining the relationship between ethno-religious identification and support for intergroup violence. According to contact theory, more contact between ethnoreligious groups is likely to reduce out-group prejudice (Allport 1954). There is ample evidence that intergroup contact improves attitudes towards the out-group (Pettigrew and Tropp 2006; Pettigrew et al. 2011). Moreover, it has been argued and shown that the positive effect of intergroup contact is particularly strong for the quality of contact, which fulfills Allport's (1954) conditions for optimal contact effect, namely equal status, common goals, cooperation, and institutional support (Pettigrew et al. 2011).

Whereas most of the literature on intergroup contact has focused on Western countries, there is growing empirical evidence for a positive role of intergroup contact in non-western contexts, with a history of intergroup violence and where contemporary intergroup relations remain tense (Tausch, Hewstone, and Roy 2009; Rydgren, Sofi, and Hällsten 2013; Kanas, Scheepers, and Sterkens 2015; Kanas, Scheepers, and Sterkens 2017b; Putra and Wagner 2017).

In this study, we follow up on this recently growing research and examine the hypothesis that the lower quality of intergroup contact can partly explain the positive relationship between ethno-religious identification and support for violence. The principal reason for this expectation is that people who strongly identify with their ethno-religious in-group may abstain from developing and maintaining high-quality intergroup contact to avoid consequences of social and institutional sanctions, as it is in the case of interfaith marriage in Indonesia (Kanas, Scheepers, and Sterkens 2017b). In this way, the (lack of) intergroup contact is driven by a preference for in-group contact rather than negativity towards the out-group (Jackson and Hunsberger 1999; Cairns et al. 2006; Verkuyten and Yildiz 2007; Licata et al. 2012; Ysseldyk et al. 2012).

More generally, in a historical context of communal violence and ongoing tensions between Christians and Muslims, we expect ethnoreligious group members to have a lower quality of intergroup contacts and, in some cases, avoid intergroup contact whatsoever, as such 
contact is likely to be associated with disloyalty to the in-group (Rydgren, Sofi, and Hällsten 2013; Kanas, Scheepers, and Sterkens 2016).

Crucially, however, we add that the partial explanation for the relationship between ethno-religious identification and support for intergroup violence due to the quality of intergroup contact may depend on individuals' prior exposure to communal conflict. Specifically, we expect that the quality of intergroup contact is less important when it is susceptible to peer pressure and fear of repercussions, which is often the case in a situation of actual violent conflict (e.g., Rydgren, Sofi, and Hällsten 2013). Based on the preceding, we hypothesize that the quality of intergroup contact explains some of the positive relationships between ethno-religious identification and support for out-group violence (Hypothesis 4). Moreover, we expect that the negative relationship between the quality of contact and support for out-group violence is weaker for those who experienced actual communal violence than those who did not (Hypothesis 5).

Figure 1 presents the conceptual model at a glance. We expect that ethno-religious identification is positively related to support for outgroup violence (Hypothesis 1). A higher perception of out-group threat and a lower quality of intergroup contact partly mediate this relationship (Hypotheses 2 and 4). Moreover, the experience of actual communal violence moderates the positive relationship between the perception of threat and support for violence on the one hand and the negative relationship between the quality of contact and support for violence on the other hand (Hypotheses 3 and 5).

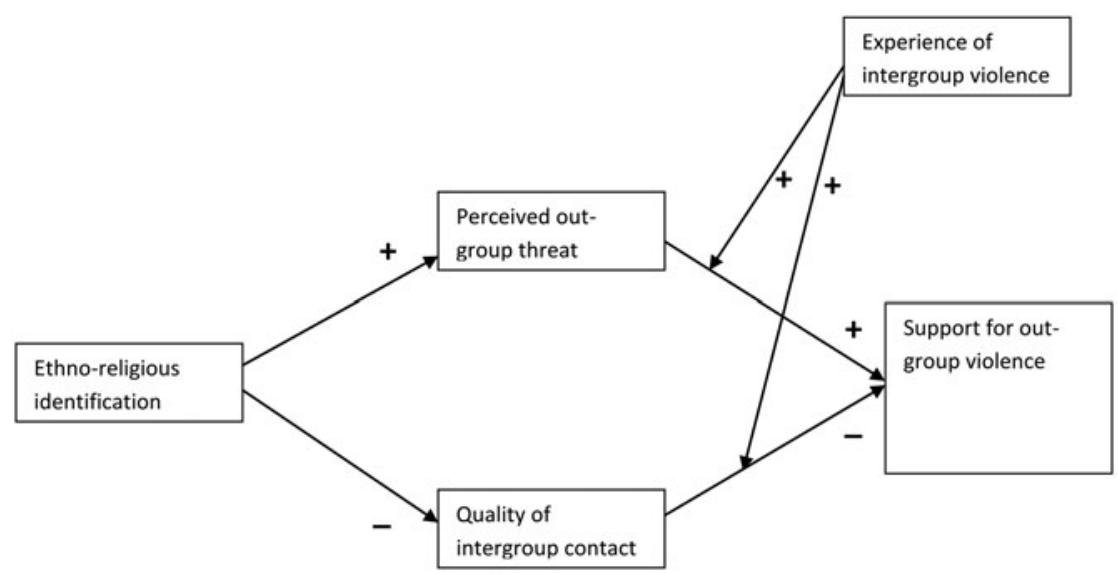

FIGURE 1. Ethno-religious identification and support for out-group violence. 


\section{DATA AND METHODS}

We tested our predictions using two large, cross-sectional surveys, "Ethno-religious conflicts in Indonesia 2012 (ERCI 2012)" and "Ethnoreligious conflicts in the Philippines 2012 (ERCP 2012)" (Sterkens et al. 2014a; 2014b), which are publicly available to researchers through DANS (https://dans.knaw.nl). The surveys were collected at the end of 2011 and the beginning of 2012 among second and third-year bachelor students in cities of Yogyakarta, Ambon (Maluku), Metro-Manila, and Marawi, Cotabato, and Iligan (in and around BARMM). In each region, we selected three universities: a public (state) university (with a majority of Muslim or Christian students dependent on the country), an Islamic university with a majority of Muslim students, and a Christian university with a majority of Christian students. The choice of public and denominational universities was to ensure a sufficient number of Christian and Muslim students in each region. In each university, a random sample of 250 students from enrollment lists took place, which resulted in a total of 3,000 respondents. Because of a small number of Muslim respondents in Metro-Manila, an additional nonrandom sample of Muslims in the Philippines' capital was added. ${ }^{3}$ In Indonesia, the questionnaires were translated into Bahasa Indonesia by two independent translators, checked by a third one in case of differences in translation. Because English is an official language in the Philippines alongside Tagalog and most university-level courses are taught in English, there was no need to translate the questionnaires for the Philippine respondents. The response rate varied among countries and research regions, and it was the highest in Ambon city (63.1\%) and the lowest in Metro-Manila (41.6\%).

The unique value of the ERCI and ERCP surveys is that they focus on conflict and non-conflict regions of Indonesia and the Philippines, thus providing insights into the processes that fuel religious extremism. In addition, the surveys contain an extensive list of questions on ethnic and religious identification, perceived intergroup threat, interreligious contact, including the frequency and quality of contact, and political activism, differentiating between legal forms of activism, i.e., protest and demonstration and illegal forms, i.e., violence. In this study, we focus on the illegal forms of activism, i.e., support for property damage and support for harm to persons.

The analysis is restricted to male and female students who reported to be either Muslim or Christian (96.7\% of the sample). Participants with missing values $16.2 \%$ (19.3\% (Indonesia) and 13.3\% (the Philippines)) 
were deleted listwise. ${ }^{4}$ The final sample consists of 1,210 (Indonesia), and 1,362 (the Philippines) participants, 55\% (Indonesia), and 22\% (the Philippines) of whom are Muslims. Women make up 45 and $65 \%$ of our respondents in Indonesia and the Philippines, respectively.

\section{Dependent variable}

Support for out-group violence was assessed with five statements about support for damage to property and five statements about support for harm to persons (Kanas and Martinovic 2017a). The wording was the following: "I would support the damaging of property/harm to persons to get more jobs for my religious group," "to fight abuse of political power against my religious group," "to enforce the political influence of my religious group," "to enforce free access to education for my religious group," and "when my religion is deeply insulted," measured on a 5-point Likert scale, ranging from 1 (totally disagree) to 5 (totally agree). We measured this intentional support rather than actual participation in out-group violence, which is typically rare and not openly discussed. So, trying to measure it would be problematic (Moskalenko and McCauley 2009). Simultaneously, research has shown that radical behavior performed by extremist individuals, such as terrorist attacks, often depends on the moral and material support of a wider group of sympathizers and supporters (Moskalenko and McCauley 2009). The items were loaded on a common factor for Christians in Indonesia and the Philippines and Muslims in the Philippines. For Muslims in Indonesia, the items were loaded on two factors, but most of the variance was accounted for by the first factor. We, therefore, combined all the items in highly reliable scales across samples: Muslims in Indonesia, $\alpha=0.89$; Christians in Indonesia, $\alpha=$ 0.94; Muslims in the Philippines $\alpha=0.91$; Christians in the Philippines, $\alpha=0.95$, with a higher score indicating stronger support for violence on behalf of the religious in-group. Approximately $14 \%$ of all respondents in total do not reject and even approves of out-group violence.

\section{Independent Variables}

Ethno-religious identification was measured with 10 statements capturing the importance of one's religious (five items) and ethnic identity (five items) (Ashmore, Deaux, and McLaughlin-Volpe 2004; Roccas, Klar, and Liviatan 2006; Verkuyten 2007). The wording was the following: 
"My religious (ethnic) identity is very important to me," "I see myself as a committed member of my religious (ethnic) group," "My religious beliefs (ethnic identity) have a great deal of influence in my daily life," "My religious beliefs (ethnic identity) have a great deal of influence on how I make important decisions," and "My religious beliefs (ethnic identity) have a great deal of influence on how I relate with others," measured on a fivepoint Likert scales ranging from 1 (totally disagree) to 5 (totally agree). A factor analysis (principal-component factor) was performed, with the number of factors fixed at one. All items were loaded on a common factor (loadings ranging from 0.5 to 0.72 ) and formed reliable scales across samples: Muslims in Indonesia, $\alpha=0.81$; Christians in Indonesia, $\alpha=0.82$; Muslims in the Philippines $\alpha=0.87$; Christians in the Philippines, $\alpha=0.87$, with a higher score indicating higher ethno-religious identification. ${ }^{5}$ The perceived intergroup threat was assessed with nine statements such as "I am worried that job prospects for members of my group would decline due to the presence of other religious groups," "I am worried that study grant opportunities will decline due to the presence of other religious groups," and "I am afraid that the customs of my group will be lost due to the presence of other religious groups," measured on a five-point Likert scales ranging from 1 (totally disagree) to 5 (totally agree) (see Appendix for the complete list of items). Similar items have been successfully used in other studies to measure perceived intergroup threat posed by ethnic and racial groups (Scheepers, Gijsberts, and Coenders 2002; Stephan et al. 2002; Gijsberts, Hagendoorn, and Scheepers 2004; Schneider 2008). Although previous studies distinguish between realistic threat and symbolic threat (e.g., Stephan et al. 2002; Stephan et al. 2009), the results from the factor analysis (principal-component factor) indicated that perceived out-group threat is one-dimensional in our sample. We combined the items to form reliable scales across samples: Muslims in Indonesia, $\alpha=0.92$; Christians in Indonesia, $\alpha=0.92$; Muslims in the Philippines $\alpha=0.88$; Christians in the Philippines, $\alpha=$ 0.92. A higher score indicates a stronger perception of intergroup threat.

Quality of intergroup contact was measured by 16 statements referring to four aspects of the quality of intergroup contact, namely goodness, closeness, equality, and cooperativeness (Allport 1954; Pettigrew and Tropp 2006). For example, the four statements for contact with friends were: "How would you rate your contact with [religious group] as friends?"; "How close are you with your friends from other religious groups?"; "How equal would you say you are with your friends from other religious groups?"; and "How much do you cooperate with your 
friends from other religious groups?," measured on a five-point scale. The same questions were repeated for contact with religious out-group neighbors, classmates, and housemates (see Appendix). We combined these items to form reliable scales across samples: Muslims in Indonesia, $\alpha=$ 0.96; Christians in Indonesia, $\alpha=0.93$; and Muslims in the Philippines, $\alpha=0.90$; Christians in the Philippines, $\alpha=0.90$ ), with a higher score indicating better interreligious contact.

The experience of out-group violence is measured by nine dichotomous statements asking whether in the past 10 years the respondents or their family, friends, or neighbors suffered any type of physical injury or death due to interreligious violence. Based on this information, we constructed a dichotomous variable taking the value one if the respondent gave a positive response to (at least) one item.

Majority status is measured by a dichotomous variable equal to one if a respondent belongs to a religious majority group at the national level, i.e., Muslims in Indonesia and Christians in the Philippines, and zero if a respondent belongs to a religious minority at the national level, i.e., Christians in Indonesia and Muslims in the Philippines.

\section{Control Variables}

We also control for the influence of three background factors that are established predictors of support for ethno-religious extremism in the examined regions (Kanas and Martinovic 2017a): gender $(1=$ male) and socioeconomic background as indicated by parental education (average of mother's and father's education, measured on a 4-point scale, ranging from 1 (no education) to 4 (tertiary education)) and household income (measured on an 8-point scale, ranging from 1 (less than $\mathrm{Rp} \mathrm{500,000/}$ PHP 3,000) to $8(\operatorname{Rp} 6,000,000 /$ PHP 45,000$))$. Since the focus is on the second- and third-year bachelor students, and there is very little variation in age $($ Mean $=21.45$, S.D. $=2.68$ (Indonesia), Mean $=19.72$, S.D. $=1.93$ (the Philippines)), we do not include age in the analyses. ${ }^{6}$

\section{Methods}

We estimated ordinary least squares (OLS) models to address our hypotheses and research questions. We checked for high multicollinearity among the independent variables, but the correlations did not exceed critical levels. However, because living in a conflict region versus a non-conflict 
region is correlated with two main predictor variables (i.e., perceived outgroup threat and the experience of actual interreligious violence), it was not included in the analyses.

\section{RESULTS}

Table 1 presents descriptive statistics for the independent and dependent variables. Tables 2 and 3 present the results from the OLS regression of support for violence. Model 1 includes ethno-religious identification and control variables; Model 2 adds the perception of intergroup threat and the quality of contact; and Model 3 includes additional interactions between perceived intergroup threat and the quality of contact on the one hand and experience of actual violence, on the other. To see whether the same patterns emerge in both countries and among religious majorities and minorities, the models are estimated separately for Indonesia and the Philippines and religious majorities and minorities (cf. Tables 2, 3). Finally, we followed these regression analyses up with bootstrap tests of mediation (MacKinnon, Krull, and Lockwood 2000; Preacher and Hayes 2008; Hayes 2018) to examine whether the relationship between ethno-religious identification and support for violence is mediated by out-group threat/quality of contact.

Table 1. Descriptive statistics

\begin{tabular}{|c|c|c|c|c|c|}
\hline & \multirow[b]{2}{*}{ Range } & \multicolumn{2}{|c|}{ Indonesia } & \multicolumn{2}{|c|}{ Philippines } \\
\hline & & Mean & S.D. & Mean & S.D. \\
\hline \multicolumn{6}{|l|}{ Dependent variables } \\
\hline Support for violence & $1-5$ & 2.02 & 0.72 & 2.00 & 0.83 \\
\hline \multicolumn{6}{|l|}{ Independent variables } \\
\hline Ethno-religious identification & $1-5$ & 3.92 & 0.56 & 3.94 & 0.62 \\
\hline Perceived group threat & $1-5$ & 2.43 & 0.77 & 2.39 & 0.78 \\
\hline Quality of contact & $1-5$ & 3.78 & 0.77 & 3.94 & 0.55 \\
\hline Experience of violence & $0 / 1$ & 0.40 & 0.49 & 0.24 & 0.43 \\
\hline \multicolumn{6}{|l|}{ Control variables } \\
\hline Muslim & $0 / 1$ & 0.55 & 0.50 & 0.22 & 0.41 \\
\hline Male & $0 / 1$ & 0.52 & 0.50 & 0.35 & 0.48 \\
\hline Parental education & $0-3$ & 2.11 & 0.69 & 2.68 & 0.52 \\
\hline Household income & $1-8$ & 4.02 & 2.35 & 5.31 & 2.15 \\
\hline Number of observations & 1,210 & \multicolumn{4}{|c|}{1,362} \\
\hline
\end{tabular}

Source: ERCI 2012, ERCP 2012. 
Table 2. OLS regression analyses of support for out-group violence, separate per country

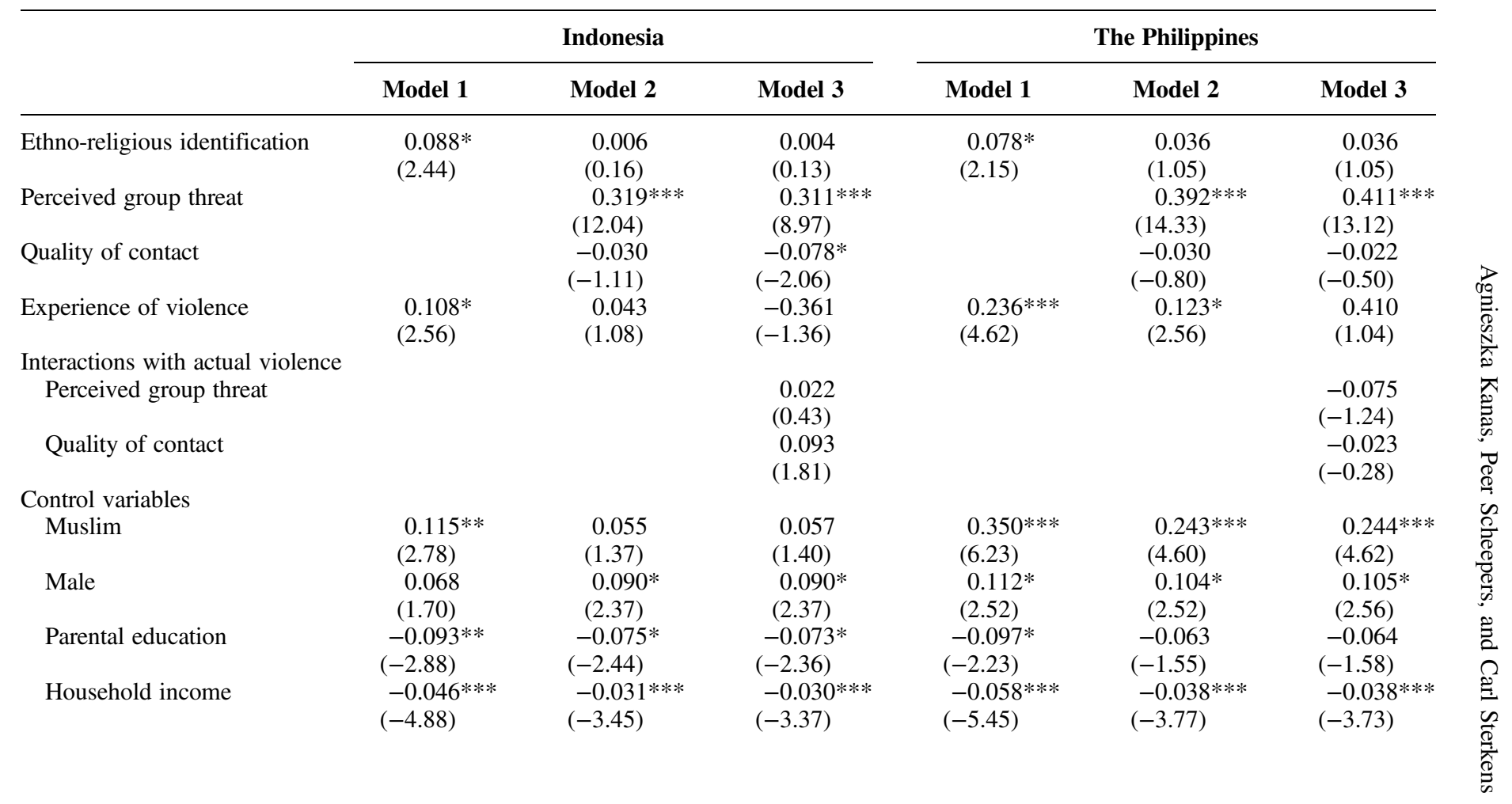


Table 2. Continued

\begin{tabular}{|c|c|c|c|c|c|c|}
\hline & \multicolumn{3}{|c|}{ Indonesia } & \multicolumn{3}{|c|}{ The Philippines } \\
\hline & Model 1 & Model 2 & Model 3 & Model 1 & Model 2 & Model 3 \\
\hline Constant & $\begin{array}{l}1.918 * * * \\
(12.13)\end{array}$ & $\begin{array}{l}1.525^{* * * *} \\
(8.09)\end{array}$ & $\begin{array}{l}1.722 * * * \\
(7.65)\end{array}$ & $\begin{array}{l}2.083^{* * * *} \\
(11.25)\end{array}$ & $\begin{array}{l}1.278^{* * * *} \\
(5.53)\end{array}$ & $\begin{array}{l}1.204 * * * \\
(4.79)\end{array}$ \\
\hline Adjusted $R$-squared & 0.067 & 0.178 & 0.179 & 0.120 & 0.245 & 0.244 \\
\hline Number of observations & 1,210 & 1,210 & 1,210 & 1,362 & 1,362 & 1,362 \\
\hline
\end{tabular}

$t$-statistics in parentheses; $* p<0.05, * * p<0.01, * * * p<0.001$, two-tailed test. Source: ERCI 2012, ERCP 2012. 
Table 3. OLS Regression analyses of support for out-group Violence, separate for religious majorities and minorities

\begin{tabular}{|c|c|c|c|c|c|c|}
\hline & \multicolumn{3}{|c|}{ Majorities } & \multicolumn{3}{|c|}{ Minorities } \\
\hline & Model 1 & Model 2 & Model 3 & Model 1 & Model 2 & Model 3 \\
\hline Ethno-religious identification & $0.107 * * *$ & 0.028 & 0.028 & 0.020 & -0.005 & -0.001 \\
\hline & $(3.50)$ & $(0.97)$ & $(0.99)$ & $(0.43)$ & $(-0.12)$ & $(-0.03)$ \\
\hline Perceived group threat & & $\begin{array}{l}0.361 * * * \\
(15.61)\end{array}$ & $\begin{array}{l}0.359 * * * \\
(13.47)\end{array}$ & & $\begin{array}{l}0.356^{* * * *} \\
(10.52)\end{array}$ & $\begin{array}{l}0.394 * * * \\
(8.47)\end{array}$ \\
\hline Quality of contact & & $\begin{array}{l}-0.033 \\
(-1.30)\end{array}$ & $\begin{array}{l}-0.069^{*} \\
(-2.19)\end{array}$ & & $\begin{array}{l}-0.012 \\
(-0.26)\end{array}$ & $\begin{array}{c}-0.033 \\
(-0.51)\end{array}$ \\
\hline Experience of violence & $\begin{array}{l}0.207 * * * \\
(4.92)\end{array}$ & $\begin{array}{l}0.112 * * \\
(2.83)\end{array}$ & $\begin{array}{l}-0.256 \\
(-0.98)\end{array}$ & $\begin{array}{c}0.099 \\
(1.87)\end{array}$ & $\begin{array}{c}0.021 \\
(0.42)\end{array}$ & $\begin{array}{c}0.036 \\
(0.08)\end{array}$ \\
\hline \multicolumn{7}{|l|}{ Interactions with actual violence } \\
\hline Perceived group threat & & & $\begin{array}{c}0.007 \\
(0.13)\end{array}$ & & & $\begin{array}{c}-0.080 \\
(-1.23)\end{array}$ \\
\hline Quality of contact & & & $\begin{array}{c}0.095 \\
(1.89)\end{array}$ & & & $\begin{array}{c}0.046 \\
(0.51)\end{array}$ \\
\hline \multicolumn{7}{|l|}{ Control variables } \\
\hline Muslim & $\begin{array}{c}0.013 \\
(0.32)\end{array}$ & $\begin{array}{l}-0.006 \\
(-0.15)\end{array}$ & $\begin{array}{c}-0.004 \\
(-0.10)\end{array}$ & $\begin{array}{l}0.498^{* * *} \\
(8.13)\end{array}$ & $\begin{array}{l}0.354 * * * \\
(6.00)\end{array}$ & $\begin{array}{l}0.353^{* * * *} \\
(5.98)\end{array}$ \\
\hline Male & $\begin{array}{c}0.066 \\
(1.83)\end{array}$ & $\begin{array}{l}0.089 * * \\
(2.64)\end{array}$ & $\begin{array}{l}0.088^{* *} \\
(2.61)\end{array}$ & $\begin{array}{l}0.121 * \\
(2.26)\end{array}$ & $\begin{array}{l}0.101^{*} \\
(2.01)\end{array}$ & $\begin{array}{l}0.106 * \\
(2.10)\end{array}$ \\
\hline Parental education & $\begin{array}{l}-0.108 * * \\
(-3.25)\end{array}$ & $\begin{array}{l}-0.077 * \\
(-2.47)\end{array}$ & $\begin{array}{l}-0.078 * \\
(-2.50)\end{array}$ & $\begin{array}{l}-0.060 \\
(-1.36)\end{array}$ & $\begin{array}{l}-0.054 \\
(-1.30)\end{array}$ & $\begin{array}{l}-0.053 \\
(-1.27)\end{array}$ \\
\hline Household income & $\begin{array}{l}-0.042 * * * \\
(-4.73)\end{array}$ & $\begin{array}{l}-0.024 * * \\
(-2.88)\end{array}$ & $\begin{array}{l}-0.023 * * \\
(-2.77)\end{array}$ & $\begin{array}{l}-0.067 * * * \\
(-5.39)\end{array}$ & $\begin{array}{l}-0.051^{* * *} \\
(-4.36)\end{array}$ & $\begin{array}{l}-0.050 * * * \\
(-4.27)\end{array}$ \\
\hline Constant & $\begin{array}{l}1.924^{* * *} \\
(12.96)\end{array}$ & $\begin{array}{l}1.356 * * * \\
(7.93)\end{array}$ & $\begin{array}{l}1.496^{* * * *} \\
(7.86)\end{array}$ & $\begin{array}{l}2.192 * * * \\
(10.54)\end{array}$ & $\begin{array}{l}1.463 * * * \\
(5.27)\end{array}$ & $\begin{array}{l}1.434^{* * * *} \\
(4.05)\end{array}$ \\
\hline
\end{tabular}


Table 3. Continued

\begin{tabular}{|c|c|c|c|c|c|c|}
\hline & \multicolumn{3}{|c|}{ Majorities } & \multicolumn{3}{|c|}{ Minorities } \\
\hline & Model 1 & Model 2 & Model 3 & Model 1 & Model 2 & Model 3 \\
\hline Adjusted $R$-squared & 0.079 & 0.206 & 0.206 & 0.111 & 0.219 & 0.219 \\
\hline Number of observations & 1,699 & 1,699 & 1,699 & 873 & 873 & 873 \\
\hline
\end{tabular}

$t$-statistics in parentheses; $* p<0.05, * * p<0.01, * * * p<0.001$, two-tailed test. Source: ERCI 2012, ERCP 2012. 
Our first hypothesis stated that ethno-religious identification is positively related to support for out-group violence. Table 2, Model 1, clearly supports this hypothesis. In both Indonesia and the Philippines, we find a positive relationship between ethno-religious identification and support for intergroup violence. That is, keeping other variables constant, a change from low to high ethno-religious identification is associated with an increase in ethno-religious identification by $0.35(4 \times 0.088)$ in Indonesia and $0.31(4 \times 0.078)$ points in the Philippines. Our second hypothesis stated that perceived intergroup threat (partly) mediates the positive relationship between ethno-religious identification and support for out-group violence (Hypothesis 2). We find support for this hypothesis in both Indonesia and the Philippines. First, Table 2, Model 2 clearly shows that in both countries, the perception of intergroup threat is positively related to support for out-group violence. Second, the coefficient for ethno-religious identification on support for out-group violence is significantly reduced in magnitude when the perception of threat is included in the model: $b=0.088, p=0.036$ (Indonesia) and $b=0.078, p=0.032$ (the Philippines) in Model 1 versus $b=0.006, p=0.872$ (Indonesia) and $b=0.036, p=0.293$ (the Philippines) in Model 2. Additional analyses presented in the Appendix (Table A1) show that ethno-religious identification is positively significantly related to the perception of out-group threat: $b=$ $0.255, p<0.001$ (Indonesia) and $b=0.140, p<0.001$ (the Philippines). We followed these regression analyses up with bootstrap tests of mediation (Preacher and Hayes 2008; Hayes 2018) and confirmed that perceived out-group threat mediates the positive relationship between ethno-religious identification and support for violence in Indonesia: indirect effect $=$ 0.090 , S.E. $=0.017,95 \%$ confidence interval: 0.057 and 0.123 ; and in the Philippines: indirect effect $=0.05$, S.E. $=0.016$, 95\% confidence interval: 0.017 and 0.082 .

Our third hypothesis stated that the relationship between perceived outgroup threat and support for out-group violence is significantly stronger for those who experienced actual communal violence than those who did not. The results presented in Table 2, Model 3, provide no support for this hypothesis. Specifically, while we find that experience of violence induces support for violence (cf. Model 1, Table 2), there is no evidence that it strengthens the relationship between the perception of threat and support for violence. Importantly, these findings are the same in both countries. Interestingly, the perceived intergroup threat remains a strong predictor of support for violence, even when the actual experience of violence is taken into account. In sum, our results suggest that the perception 
of threat provides a valid mechanism explaining the relationship between ethno-religious identification and support for violence. However, there is no evidence that the positive relationship between perceived intergroup threat and support for violence is stronger among those who experienced actual violence.

In our fourth hypothesis, as a corollary to Hypothesis 2, we expected that the quality of intergroup contact explains the positive relationship between ethno-religious identification and support for violence. Our results presented in Table 2, Model 2 clearly reject this hypothesis as the relationship between the quality of contact and support for outgroup violence, while negative, does not reach statistical significance, and this holds in both countries. The results from additional analyses, not presented in Table 2, show that when perceived intergroup threat is not included in the model, the quality of contact is negatively and significantly related to support for violence in both Indonesia and the Philippines ( $b=-0.116, p<0.001$ and $b=-0.161, p<0.001$, respectively). These results suggest that the negative relationship between the quality of contact and support for out-group violence is influenced by the inclusion of perceived group threat in the model. It could be that people with higher quality intergroup contacts are less likely to perceive the intergroup threat and, because of that, less likely to support interreligious violence (Stephan et al. 2002; McLaren 2003). Alternatively, one could argue that a high perception of group threat prevents people from developing meaningful ties with out-group members inducing support for intergroup violence (McLaren 2003). With cross-sectional data, examining which of the mechanisms proposed is stronger is beyond this paper's scope.

The fifth hypothesis stated that a possible negative relationship between the quality of contact and support for out-group violence would be weaker among those who experienced actual communal violence. Our results provide merely weak evidence for this hypothesis as indicated by the positive and marginally significant interaction effect between the quality of contact and experience of actual violence in the Indonesian sample. Specifically, Table 2, Model 3 shows that while the quality of intergroup contact is negatively related to support for interreligious violence, the positive and marginally significant interaction effect between the quality of contact and actual violence suggests that this is largely among those without experience of violence. There is no evidence that the quality of interreligious contact is directly related to the support for interreligious violence in the Filipino sample, and this is regardless of the experience of actual violence. 
In all estimated models and in line with previous research (Subagya 2015; Kanas and Martinovic 2017a), males and students coming from lower socio-economic backgrounds, as indicated by parental education and household income, report higher support for out-group violence than females and those who come from a higher socio-economic background. There is also some evidence that Filipino Muslims show more support for intergroup violence than Filipino Christians (cf. Table 2). This result is not surprising, given that most Muslims in the Filipino sample live or come from the country's most impoverished region of Mindanao, with a recent history of communal violence. Despite decennia-long peace negotiations and development programs, Muslims in the region still live in a context of social instability and poor living standards (Hutchcroft 2015). Living conditions hit rock bottom shortly after our data collection during the 5-month-long Battle of Marawi from May 2017 onwards, resulting in more than a thousand deadly victims and many more displaced (Australian Strategic Policy Institute 2019; International Crisis Group 2019).

\section{DIFFERENCES BETWEEN RELIGIOUS MAJORITIES AND MINORITIES}

In additional analyses, we examined the robustness of our findings among religious majorities and minorities and test whether majority groups perceive minorities as a more significant threat than the other way around, as Blumer (1958) proposed, resulting in more support for out-group violence among majority groups. Table 3 presents the OLS regression results of support for violence separately for religious majorities and minorities. Because the findings were very similar across two countries (cf. Table 2) and running separate analyses per country would result in a relatively small sample size, particularly for Muslims in the Philippines, we present the results for two surveys combined. Interestingly, Table 3, Model 1 shows that ethno-religious identification is positively related to support for violence among religious majorities $(b=0.107, p<0.001)$ but not among minorities $(b=-0.005, p=0.907) .^{7}$

Table 3, Model 2, and Table A2 show that perceived out-group threat mediates the relationship between ethno-religious identification and support for violence among religious majorities (indirect effect $=0.087$, S.E. $=0.014,95 \%$ confidence interval: 0.059 and 0.115. However, similar to our previous findings presented in Table 2, there is no evidence 
that intergroup contact quality mediates the positive relationship between ethno-religious identification and support for interreligious violence, and this is for both religious majorities and minorities. Additional results reveal that intergroup contact's quality is negatively related to support for out-group violence among both religious majorities and minorities. However, this negative relationship becomes insignificant when the perception of out-group threat is taken into account.

Interestingly, Table 3, Model 3 provides some evidence that the negative relationship between the quality of contact and support for violence is significantly weaker for majority group members who experienced actual violence than those who did not experience violence.

\section{DISCUSSION}

This study examines the relationship between ethno-religious identification and support for out-group violence. Over and beyond focusing on a direct relationship between ethno-religious identification and out-group hostility, we examine two complementary mediating mechanisms-the perception of out-group threat and the quality of intergroup contact-as well as the role of actual out-group violence as a moderator of these relationships. The study relies on unique survey data collected in ethnically and religiously diverse regions of Indonesia and the Philippines, where social cleavages occur along ethnic and religious lines and relations between the two largest religious communities-Christians and Muslims-are tense and have been violent. Finally, our focus on support for out-group violence provides an important contribution to previous research, predominantly focused on less radical indicators of out-group derogation, namely, negative attitudes towards the out-group, providing fewer insights into intentional behavior.

In line with our expectations, we find evidence for a positive relationship between ethno-religious identification and support for violence. These conclusions are in line with meta-analytic overviews by Jackson and Hunsberger (1999) and Hall, Matz, and Wood (2010), who reported a consistent positive relationship between religious identification and prejudice towards ethnic minorities in Western countries. In line with these findings, our results show a positive relationship between ethno-religious identification and support for interreligious violence in Indonesia and the Philippines and among religious majorities, providing reasons to propose that these results are valid across national contexts and groups with a dominant numerical size and political power. 
As hypothesized, perceived out-group threat provides an important mechanism explaining the positive relationship between ethno-religious identification and support for violence. In fact, when the perception of intergroup threat is included in the analyses, the positive relationship between ethno-religious identification and support for violence is reduced to non-significance. This implies that ethno-religious identification is positively related to the perception of intergroup threat, which is positively associated with the support for violence (Riek, Mania, and Gaertner 2006). However, because we rely on cross-sectional data, we cannot make strong causal inferences about these relationships. Under a reversed causality scenario, it could be that the perception of out-group threat increases identification with an ethnic and religious in-group, which in turn is positively related to support for violence (Moskalenko, McCauley, and Rozin 2006).

Interestingly, while the experience of communal conflict generally increases support for violence, it does not strengthen the positive relationship between perceived threat and support for violence. This implies that the perception of intergroup threat and violence experience have independent effects on support for violence. Thus, when the ethno-religious outgroup is perceived as threatening, support for out-group violence is equally strong among those with and without violence experience.

In sum, these findings suggest that experience of violence is not a necessary condition to induce support for violence and that the perception of out-group threat can be equally powerful in predicting support for intergroup conflict. This finding is in line with previous research from Western countries, which showed that the perception of intergroup threat explains the relationship between actual intergroup threat, as indicated by the size of the out-group population in the region and out-group prejudice (Schlueter and Wagner 2008).

We find, however, no support for the hypothesis that the quality of interreligious contact mediates the relationship between ethno-religious identification and support for violence. While we find that the quality of intergroup contact is negatively related to support for out-group violence, in line with existing studies on intergroup prejudice, this negative relationship becomes insignificant - and is thus explained away-when the perception of intergroup threat is taken into account (Stephan et al. 2002; McLaren 2003; Kanas, Scheepers, and Sterkens 2015). Moreover, the negative relationship between the quality of intergroup contact and support for violence seems to be particularly true for those without experience of communal violence. For those who experienced communal violence, intergroup contact quality does not influence support for violence. 
A limitation of this study is that the analyses have been based on crosssectional data. This means that all results observed in this study are correlational. While the causal order from the experience of actual intergroup violence (which occurred in the past) and support for interreligious violence is rather self-evident and previous research supports the causal order guiding the present analyses, other causal relations assumed in this research are less clear but probable. For example, consistent with our assumption, there has been strong empirical evidence from experimental (Stephan et al. 2002; Riek, Mania, and Gaertner 2006) and longitudinal analyses (Schlueter and Wagner 2008) that intergroup contact reduces and perceived intergroup threat increases out-group prejudice (Pettigrew and Tropp 2006; Pettigrew et al. 2011). Still, further work on the issue of causal relationships between group identification, on the one hand, and perceived intergroup threat and intergroup contact, on the other hand, is undoubtedly needed.

Another issue is the limited generalizability of our samples, which focuses on a student population in four regions of Indonesia and the Philippines. The choice of the student population was motivated by previous insights recognizing Indonesian and Filipino students as important politicized middle grounds between militias and groups of perpetrators on the one hand and ethnoreligious groups on the other hand (Magdalena 1977; Montiel and Macapagal 2006). Another reason was that students more than other segments of Indonesian and Filipino society, have sufficient knowledge and experience to report on theoretical concepts such as ethnic and religious identifications and the quality of outgroup contact examined in this study.

\section{CONCLUSIONS}

This study provides important insights into mechanisms and conditions under which ethno-religious identification is related to support for outgroup violence. Strong ethno-religious identification is positively and significantly related to out-group violence. This is because identification with the ethnic and religious in-group increases perceptions of out-group threat, which induces support for violence. The experience of actual violence, while an important determinant of support for violence on its own, is not a necessary condition to induce stronger support for out-group violence. While the quality of intergroup contact does not explain the positive relationship between ethno-religious identification and support for 
violence, there is some evidence that it reduces support for violence, although indirectly, via the decreased perception of out-group threat. While these findings are consistent across the two national contexts, they mainly hold among religious majorities which dominate in numerical size and have the most political power.

\title{
Financial support
}

\author{
Funding for work on this article came from the Dutch National Science \\ Foundation under programme of Conflict and Security.
}

\section{Data}

\author{
All data/additional analyses requests should be sent to Agnieszka Kanas, \\ e-mail: kanas@essb.eur.nl
}

\section{NOTES}

1. The exact numbers in the latest national cenuses are: Christians 60\% and Muslims $40 \%$ (Ambon city); Christians 9\% and Muslims 91\% (greater Yogyakarta) (Statistics Indonesia 2010); Christians 8\% and Muslims 90\% (BARMM); and Christians 95\% and Muslims 0.6\% (Metro-Manila) (NSO 2010).

2. For a detailed account of a situation in Ambon and Mindanao see the reports of the International Crisis Group (ICG 2002; 2012a; 2012b; 2019; 2020a; 2020b).

3. In total, 59 additional respondents were added in Metro-Manila sample, of which 29 came from the pilot survey and 30 were contacted via religious organizations and mosques.

4. The missing values are mainly due to missing information on the quality of contact (9\%), household income (2\%), and parental education $(1 \%)$.

5. Besides ethnic and religious identification, national identification is another factor contributing to support for political action (Hayes and McAllister 2001; Kanas and Martinovic 2017a). National identification may be particularly important for aggravated minorities, for whom identifying with both ethnic and religious in-group and national society can contribute to the feeling of being part of the larger national society and legitimize political action on behalf of the in-group (e.g., Klandermans, Van der Toorn, and Van Stekelenburg, 2008). However, in our context, to the extent that ethnic and religious majorities experience shared grievances, dual identification may promote political action among majority group members as well. We re-estimated our models with national identification as a control variable for the Indonesian sample which includes measures of national identification (see the Appendix). While there is some evidence that national identification is negatively related to support for out-group violence $(b=-0.063, p=0.088)$, the relationship between ethno-religious identification and support for violence remains negative and statistically significant. These findings suggest that at least in Indonesia, the positive relationship between ethno-religious identification and support for violence cannot be explained by higher levels of national identification among aggravated communities.

6. To see whether the estimated relationship are influenced by the factor of youth, we re-estimated analyses with age of respondents as a control variable. Additional results show that while age has a negative effect on support for out-group violence in Indonesia, this effect becomes insignificant after the perception of threat and the quality of contact are included in the analyses (cf. Model 2). In addition, age has no significant effect on support for violence in the Philippines and among religious majorities and minorities. More importantly, controlling for age does not affect our conclusions regarding the role of ethno-religious identification in support for violence. 
7. We also examined whether the relationship between ethno-religious identification and support for violence is significantly stronger among religious majorities than minorities (cf. Model 1, Table 3), by estimating the interaction between ethno-religious identification and majority status in the combined model (cf., Table 2). The results show that the interaction is positive and marginally significant $(p<0.09)$ in the Filipino sample.

\section{REFERENCES}

Allport, G. W. 1954. The Nature of Prejudice. Reading, MA: Addison Wesley.

Ashmore, R.D., K. Deaux, and T. McLaughlin-Volpe. 2004. "An Organizing Framework for Collective Identity: Articulation and Significance of Multidimensionality." Psychological Bulletin 130:80.

Australian Strategic Policy Institute. 2019. The Marawi Crisis. Urban Conflict and Information Operations. Barton: ASPI.

Bauman, C., and T. Leech. 2012. "Political Competition, Relative Deprivation, and Perceived Threat: A Research Note on Anti-Christian Violence in India." Ethnic and Racial Studies 35:2195-2216.

Blumer, H. 1958. "Race Prejudice as A Sense of Group Position." Pacific Sociological Review 1:3-7.

Brewer, M. B. 1999. "The Psychology of Prejudice: In-Group Love or out-Group Hate?" Journal of Social Issues 55:429-444.

Cairns, E., J. Kenworthy, A. Campbell, and M. Hewstone. 2006. "The Role of in-Group Identification, Religious Group Membership and Intergroup Conflict in Moderating in-Group and out-Group Affect." British Journal of Social Psychology 45:701-716.

Gijsberts, M., L. Hagendoorn, and P. Scheepers. 2004. Nationalism and Exclusion of Migrants: Cross National Comparisons. Burlington, VT: Ashgate Publishing Company.

Hall, D. L., D. C. Matz, and W Wood. 2010. "Why Don't We Practice What we Preach? A Meta-Analytic Review of Religious Racism." Personality and Social Psychology Review 14:126-139.

Hayes, A. F. 2018. Introduction to Mediation, Moderation, and Conditional Process Analysis. A Regression-Based Approach. New York: Guilford Press.

Hayes, B. C., and I. McAllister. 2001. "Sowing Dragon's Teeth: Public Support for Political Violence and Paramilitarism in Northern Ireland." Political Studies 49:901-922.

Hinkle, S., and R. Brown. 1990. "Intergroup Comparisons and Social Identity: Some Links and Lacunae." Social Identity Theory: Constructive and Critical Advances 48:70.

Hutchcroft, P. D. 2015. Mindanao. The Long Journey to Peace and Prosperity. Singapore: World Scientific Publishing.

International Crisis Group Asia Briefing 133. 2012a. Indonesia: Cautious Calm in Ambon. Jakarta/Brussels: International Crisis Group.

International Crisis Group Asia Report 250. 2012b. Philippines: Breakthrough in Mindanao. Jakarta/Brussels: International Crisis Group.

International Crisis Group Asia Report 301. 2019. The Philippines: Militancy and the New Bangsamoro. Jakarta/Brussels: International Crisis Group.

International Crisis Group Asia Report 302. 2020a. The Philippines: Tackling Clan Politics in the Bangsamoro. Jakarta/Brussels: International Crisis Group.

International Crisis Group Asia Report 306. 2020b. Southern Philippines: Tackling Clan Politics in the Bangsamoro. Jakarta/Brussels: International Crisis Group.

International Crisis Group Asia Report 31. 2002. Indonesia: The Search for Peace in Maluku. Executive Summary and Recommendations. Jakarta/Brussels: International Crisis Group. 
Jackson, L. M., and B. Hunsberger 1999. "An Intergroup Perspective on Religion and Prejudice." Journal for the scientific study of religion 38:509-523.

Kanas, A., and B. Martinovic. 2017a. "Political Action in Conflict and Non-Conflict Regions in Indonesia: The Role of Religious and National Identifications." Political Psychology 38:209-225.

Kanas, A., P. Scheepers, and C. Sterkens. 2015. "Interreligious Contact, Perceived Group Threat, and Perceived Discrimination: Predicting Negative Attitudes Among Religious Minorities and Majorities in Indonesia." Social Psychology Quarterly 78:102-126.

Kanas, A., P. Scheepers, and C. Sterkens. 2016. "Religious Identification and Interreligious Contact in Indonesia and the Philippines: Testing the Mediating Roles of Perceived Group Threat and Social Dominance Orientation and the Moderating Role of Context." European Journal of Social Psychology 46:700-715.

Kanas, A., P. Scheepers, and C. Sterkens. 2017b. "Positive and Negative Contact and Attitudes Towards the Religious out-Group: Testing the Contact Hypothesis in Conflict and non-Conflict Regions of Indonesia and the Philippines." Social Science Research 63:95-110.

Klandermans, B., J. Van der Toorn, and J. Van Stekelenburg. 2008. "Embeddedness and Identity: How Immigrants Turn Grievances Into Action." American Sociological Review 73:992-1012.

Licata, L., O. Klein, W. Saade, A. E. Azzi, and N. R. Branscombe. 2012. "Perceived outGroup (dis)Continuity and Attribution of Responsibility for the Lebanese Civil War Mediate Effects of National and Religious Subgroup Identification on Intergroup Attitudes." Group Processes and Intergroup Relations 15:179-192.

MacKinnon, D. P., J. L. Krull, and C. M Lockwood. 2000. "Equivalence of the Mediation, Confounding and Suppression Effect." Prevention Science 1:173-181.

Magdalena, F. V. 1977. "Intergroup Conflict in the Southern Philippines: An Empirical Analysis." Journal of Peace Research 14:299-313.

Maoz, I., and C. McCauley. 2009. "Threat Perceptions and Feelings as Predictors of Jewish-Israeli Support for Compromise with Palestinians." Journal of Peace Research 46:525-539.

McLaren, L. M. 2003. "Anti-Immigrant Prejudice in Europe: Contact, Threat Perception, and Preferences for the Exclusion of Migrants." Social Forces 81:909-936.

Montiel, C. J., and M. E. J. Macapagal 2006. "Effects of Social Position on Societal Attributions of an Asymmetric Conflict." Journal of Peace Research 43:219-227.

Moskalenko, S., and C. McCauley. 2009. "Measuring Political Mobilization: The Distinction Between Activism and Radicalism." Terrorism and Political Violence 21:239-260.

Moskalenko, S., C. McCauley, and P. Rozin. 2006. "Group Identification Under Conditions of Threat: College Students' Attachment to Country, Family, Ethnicity, Religion, and University Before and After September 11." Political Psychology 27:77-97.

Mujiburrahman. 2006. Feeling Threatened: Muslim-Christian Relations in Indonesia's New Order. Amsterdam: Amsterdam University Press.

NSO National Statistics Office, Republic of the Philippines. 2010. Retrieved in January 2012, from: www.census.gov.ph.

Pettigrew, T. F., and L. R. Tropp. 2006. "A Meta-Analytic Test of Intergroup Contact Theory." Journal of Personality and Social Psychology 90:751-783.

Pettigrew, T. F., L. R. Tropp, U. Wagner, and O. Christ. 2011. "Recent Advances in Intergroup Contact Theory." International Journal of Intercultural Relations 35:271-280.

Pew Research Center. 2019. A Closer Look at How Religious Restrictions Have Risen Around the World. Washington, DC. 
Preacher, K. J., and A. F. Hayes. 2008. "Asymptotic and Resampling Strategies for Assessing and Comparing Indirect Effects in Multiple Mediator Models." Behavior Research Methods 40:879-891.

Putra, I. E., and W. Wagner. 2017. "Prejudice in Interreligious Context: The Role of Metaprejudice and Majority-Minority Status." Journal of Community \& Applied Social Psychology 27:226-239.

Quillian, L. 1995. "Prejudice as A Response to Perceived Group Threat: Population Composition and Anti-Immigrant and Racial Prejudice in Europe." American Sociological Review 60:586-611.

Riek, B. M., E. W. Mania, and S. L. Gaertner. 2006. "Intergroup Threat and Outgroup Attitudes: A Meta-Analytic Review." Personality and Social Psychology Review 10:336-353.

Roccas, S., Y. Klar, and I. Liviatan. 2006. "The Paradox of Group-Based Guilt: Modes of National Identification, Conflict Vehemence, and Reactions to the in-Group's Moral Violations." Journal of Personality and Social Psychology 91:698-711.

Roccas, S., L Sagiv, S. Schwartz, N. Halevy, and R. Eidelson. 2008. "Toward A Unifying Model of Identification with Groups: Integrating Theoretical Perspectives." Personality and Social Psychology Review 12:280-306.

Rouhana, N. N., and D. Bar-Tal. 1998. "Psychological Dynamics of Intractable Ethnonational Conflicts. The Israeli- Palestinian Case." American Psychologist 53:761-770.

Rowatt, W. C., A. Ottenbreit, K. P. Nesselroade, and P. A. Cunningham. 2002. "On Being Holier-than-Thou or Humbler-than-Thee: A Social-Psychological Perspective on Religiousness and Humility." Journal for the Scientific Study of Religion 41:227-237.

Rydgren, J., D. Sofi, and M. Hällsten. 2013. "Interethnic Friendship, Trust, and Tolerance: Findings From Two North Iraqi Cities." American Journal of Sociology 118:16501694.

Scheepers, P., and R. M. Eisinga 2015. "Religiosity and Prejudice Against Minorities." In International Encyclopedia of the Social and Behavioral Sciences, ed. J. Wright, 2nd edition. London, United Kingdom: Elsevier Health Sciences, 381-383.

Scheepers, P., M. Gijsberts, and M. Coenders. 2002. "Ethnic Exclusionism in European Countries: Public Opposition to Civil Rights for Legal Migrants as a Response to Perceived Ethnic Threat." European Sociological Review 18:17-34.

Schlueter, E., and U Wagner. 2008. "Regional Differences Matter Examining the Dual Influence of the Regional Size of the Immigrant Population on Derogation of Immigrants in Europe." International Journal of Comparative Sociology 49:153-173.

Schmid, K., N. Tausch, M. Hewstone, J. Hughes, and E. Cairns. 2008. "The Effects of Living in Segregated vs. Mixed Areas in Northern Ireland: A Simultaneous Analysis of Contact and Threat Effects in the Context of Micro-Level Neighbourhoods." International Journal of Conflict and Violence 2:56-71.

Schneider, S. L. 2008. "Anti-Immigrant Attitudes in Europe: Out-Group Size and Perceived Ethnic Threat." European Sociological Review 24:53-67.

Schulze, K. E. 2017. "The "Ethnic" in Indonesia's Communal Conflicts: Violence in Ambon, Poso, and Sambas." Ethnic and Racial Studies 40:2096-2114.

Setiawan, T., P. L. H. Scheepers, E. B. P. de Jong, and C. J. A. Sterkens. 2021. "Support for Interreligious Conflict in Indonesia: Tests of Theories on Interethnic Threat and Distrust Versus Contact." Journal of Pacific Rim Psychology 15:1-14.

Spears, R. 2011. "Group Identities: The Social Identity Perspective." In Handbook of Identity Theory and Research, eds. S. J. Schwartz, K. Luyckx and V. L. Vignoles. New York: Springer, 201-224.

Statistics Indonesia. 2010. Retrieved in October 2015, from: http://sp2010.bps.go.id. 
Stephan, W. G., K. A. Boniecki, O. Ybarra, A. Bettencourt, K. S. Ervin, L. A. Jackson, P. S. McNatt, and C. L. Renfro. 2002. "The Role of Threats in the Racial Attitudes of Blacks and Whites." Personality and Social Psychology Bulletin 28:1242-1254.

Stephan, W.G., O. Ybarra, and K. R. Morrison. 2009. "Intergroup Threat Theory." In Handbook of Prejudice, Stereotyping, and Discrimination. Mahwah, NJ: Lawrence Erlbaum Associates, 44-55.

Sterkens, C., M. Abanes, A. Camacho, A. Kanas, P. E. Thijs, and P. Scheepers. 2014a. Ethno-religious Conflicts in the Philippines 2012 (ERCP 2012). Documentation of Surveys on Ethno-Religious Identity and Latent Intergroup Conflict (DANS Data Guide 13), eds. T. D. Nelson. Amsterdam: Pallas Publications-Amsterdam University Press.

Sterkens, C., A. Kanas, C. Pamungkas, T. Subagya, P. E. Thijs, and P. Scheepers. 2014b. Ethno-religious Conflicts in Indonesia 2012 (ERCI 2012). Documentation of Surveys on Ethno-Religious Identity and Latent Intergroup Conflict (DANS Data Guide 12). Amsterdam: Pallas Publications-Amsterdam University Press.

Subagya, T. 2015. Support for Ethno-Religious Violence in Indonesia. Yogyakarta: USD press.

Tajfel, H. 1982. "Social Psychology of Intergroup Relations." Annual Review of Psychology 33:1-39.

Tajfel, H., and J. C. Turner. 1979. "An Integrative Theory of Intergroup Conflict," In The Social Psychology of Intergroup Relations, ed. W. G., Austin and S., Worchel, Monterey, CA: Brooks-Cole, 33-47.

Tausch, N., M. Hewstone, J. Kenworthy, E. Cairns, and O. Christ. 2007. "Crosscommunity Contact, Perceived status Differences and Intergroup Attitudes in Northern Ireland: The Mediating Roles of Individual-Level vs. Group Level Threats and the Moderating Role of Social Identification." Political Psychology 28:53-68.

Tausch, N., M. Hewstone, and R. Roy. 2009. "The Relationships Between Contact, Status and Prejudice: An Integrated Threat Theory Analysis of Hindu-Muslim Relations in India." Journal of Community and Applied Social Psychology 19:83-94.

Van Bruinessen, M. 2018. "Indonesian Muslims in a Globalizing World.” RSIS Working Paper 311 (Issue May): 1-23.

Verkuyten, M. 2007. "Religious Group Identification and Inter-Religious Relations: A Study among Turkish-Dutch Muslims." Group Processes and Intergroup Relations 10:341-357.

Verkuyten, M., and A. A. Yildiz. 2007. "National (dis)Identification, and Ethnic and Religious Identity: A Study among Turkish-Dutch Muslims." Personality and Social Psychology Bulletin 33:1448-1462.

Verkuyten, M., and A. A. Yildiz. 2010. "Religious Identity Consolidation and Mobilization among Turkish Dutch Muslims." European Journal of Social Psychology 40:436-447.

Ysseldyk, R. S., A. Haslam, K. Matheson, and H. Anisman. 2012. "Love Thine Enemy? Evidence That (ir)Religious Identification can Promote Outgroup Tolerance Under Threat." Group Processes Intergroup Relations 15:105-117.

Ysseldyk, R., K. Matheson, and H. Anisman. 2010. "Religiosity as Identity: Toward an Understanding of Religion From a Social Identity Perspective." Personality and Social Psychology Review 14:60-71.

Zartman, William, and P. Terrence Hopmann. 2011. Mindanao: Understanding Conflict 2011. Johns Hopkins University: Johns Hopkins University School for Advanced International Studies. 


\section{APPENDIX}

\section{MEASUREMENT OF SELECTED VARIABLES USED IN THE ANALYSES}

Quality of contact

Goodness

- "How would you rate your contact with [religious group] as neighbors?"

- "How would you rate your contact with [religious group] as classmates?"

- "How would you rate your contact with [religious group] as housemates?"

- "How would you rate your contact with [religious group] as friends?"

The items are measured on five-point ordinal scales ranging from 1 (very negative) to 5 (very positive).

Closure

- "How close are you with your neighbors from other religious groups?"

- "How close are you with your classmates from other religious groups?"

- "How close are you with your housemates from other religious groups?"

- "How close are you with your friends from other religious groups?"

The items are measured on six-point ordinal scales ranging from 1 (not close at all) to 6 (very close).

Equality

- "How equal would you say you are with your neighbors from other religious groups?"

- "How equal would you say you are with your classmates from other religious groups?"

- "How equal would you say you are with your housemates from other religious groups?"

- "How equal would you say you are with your friends from other religious groups?"

The items are measured on six-point ordinal scales ranging from 1 (not equal at all) to 6 (very equal).

Cooperativeness

- "How much do you cooperate with your neighbors from other religious groups?"

- "How much do you cooperate with your classmates from other religious groups?"

- "How much do you cooperate with your housemates from other religious groups?"

- "How much do you cooperate with your friends from other religious groups?"

The items are measured on six-point ordinal scales ranging from 1 (do not cooperate at all) to 6 (cooperate much).

Perceived group threat 
Table A1. OLS regression analyses of perceived group threat, separate per country

\begin{tabular}{lcc}
\hline & Indonesia & The Philippines \\
\hline Ethno-religious identification & $0.255^{* * *}$ & $0.140^{* * * *}$ \\
& $(6.96)$ & $(4.19)$ \\
Quality of contact & $-0.267^{* * *}$ & $-0.335^{* * *}$ \\
& $(-9.37)$ & $(-9.42)$ \\
Experience of violence & $0.165^{* * *}$ & $0.290^{* * *}$ \\
& $(3.84)$ & $(6.17)$ \\
Control variables & & \\
Muslim & 0.028 & $0.313^{* * *}$ \\
& $(0.63)$ & $(6.05)$ \\
Male & -0.041 & 0.031 \\
& $(-0.99)$ & $(0.77)$ \\
Parental education & -0.002 & $-0.085^{*}$ \\
Household income & $(-0.06)$ & $-2.12)$ \\
Constant & $-0.038^{* * *}$ & $-0.040^{* * *}$ \\
& $(-3.90)$ & $(-4.03)$ \\
Adjusted R-squared & $2.539 * * *$ & $3.453^{* * *}$ \\
Number of observations & $(13.25)$ & $(16.52)$ \\
\hline
\end{tabular}

$t$-statistics in parentheses; $* p<0.05, * * p<0.01, * * * p<0.001$, two-tailed test.

Source: ERCI 2012, ERCP 2012.

- "I am worried that job prospects for members of my group would decline due to the presence of other religious groups."

- "I am worried that study grant opportunities will decline due to the presence of other religious groups."

- "I am worried that security in my university will decline due to the presence of students of other religious groups."

- "I am worried that the security in my neighborhood will decline due to the presence of other religious groups."

- "I am afraid of increasing violence in my neighborhood due to the presence of other religious groups."

- "The chances of getting space in a boarding house will decline due to the presence of other religious groups."

- "The migration of people of different religious groups to my community is a threat to my own religious group."

- "The religious practices of people from other religious groups threaten our own way of life."

- "I am afraid that customs of my group will be lost due to the presence of other religious groups." 
Table A2. OLS Regression analyses of perceived group threat, separate for religious majorities and minorities

\begin{tabular}{lll}
\hline & Majorities & Minorities \\
\hline Ethno-religious identification & $0.229 * * *$ & $0.103^{*}$ \\
Quality of contact & $(7.69)$ & $(2.34)$ \\
Experience of violence & $-0.267 * * *$ & $-0.358^{* * *}$ \\
& $(-10.38)$ & $(-8.12)$ \\
Control variables & $0.231^{* * *}$ & $0.217^{* * *}$ \\
Muslim & $(5.62)$ & $(4.35)$ \\
& & \\
Male & -0.020 & $0.393^{* * *}$ \\
& $(-0.47)$ & $(6.81)$ \\
Parental education & -0.035 & 0.058 \\
Household income & $(-0.98)$ & $(1.15)$ \\
& -0.037 & -0.016 \\
Constant & $(-1.13)$ & $(-0.38)$ \\
& $-0.038^{* * *}$ & $-0.038^{* *}$ \\
Adjusted $R$-squared & $(-4.38)$ & $(-3.27)$ \\
Number of observations & $2.732 * * *$ & $3.465^{* * *}$ \\
\hline
\end{tabular}

$t$-statistics in parentheses; $* p<0.05, * * p<0.01, * * * p<0.001$, two-tailed test.

Source: ERCI 2012, ERCP 2012.

The items are measured on five-point scales ranging from 1 (totally disagree) to 5 (totally agree).

\section{National identification}

I am worried that job prospects for members of my group would decline due to the presence of other religious groups.

- "I would rather be a citizen of Indonesia than of any other country in the world."

- "My most important characteristics come from my nationality."

- "I should respect my nation and its tradition."

- "I should always put national interest above ethno-religious group interest."

- "Renewing national ideas is our national task."

The items are measured on five-point ordinal scales ranging from 1 (totally disagree) to 5 (totally agree). 